\title{
Late-stage volcano geomorphic evolution of the Pleistocene San Francisco Mountain, Arizona (USA), based on high-resolution DEM analysis and ${ }^{40} \mathrm{Ar} /{ }^{39} \mathrm{Ar}$ chronology
}

\author{
Dávid Karátson • Tamás Telbisz • Brad S. Singer
}

Received: 18 September 2008 / Accepted: 1 April 2010 /Published online: 1 May 2010

(C) The Author(s) 2010. This article is published with open access at Springerlink.com

\begin{abstract}
The cone-building volcanic activity and subsequent erosion of San Francisco Mountain, AZ, USA, were studied by using high-resolution digital elevation model (DEM) analysis and new ${ }^{40} \mathrm{Ar} /{ }^{39} \mathrm{Ar}$ dating. By defining remnants or planèzes of the volcano flanks in DEM-derived images, the original edifice can be reconstructed. We propose a two-cone model with adjacent summit vents which were active in different times. The reconstructed cones were 4,460 and 4,350 m high a.s.l., corresponding to $\sim 2,160$ and $2,050 \mathrm{~m}$ relative height, respectively. New ${ }^{40} \mathrm{Ar} /{ }^{39} \mathrm{Ar}$ data allow us to decipher the chronological details of the cone-building activity. We dated the Older and Younger Andesites of the volcano that, according to previous mapping, built the stage 2 and stage 3 stratocones, respectively. The new ${ }^{40} \mathrm{Ar} /{ }^{39} \mathrm{Ar}$ plateau ages yielded 589 $556 \mathrm{ka}$ for the Older and 514-505 ka for the Younger Andesites, supporting their distinct nature with a possible dormant period between. The obtained ages imply an intense final ( $\leq 100 \mathrm{ka}$ long) cone-building activity, termi-
\end{abstract}

Editorial responsibility: M.A. Clynne

D. Karátson $(\bowtie) \cdot$ T. Telbisz

Department of Physical Geography, Eötvös University,

H-1117 Budapest Pázmány s. 1/C,

Hungary

e-mail: dkarat@ludens.elte.hu

B. S. Singer

Department of Geology and Geophysics,

University of Wisconsin-Madison,

1215 W. Dayton St.,

Madison, WI 53706, USA

Present Address:

D. Karátson

Geoscience Center Göttingen, Georg-August University,

Goldschmidstrasse 1,

37077 Göttingen, Germany nating $\sim 100 \mathrm{ka}$ earlier than indicated by previous $\mathrm{K}-\mathrm{Ar}$ ages. Moreover, ${ }^{40} \mathrm{Ar} /{ }^{39} \mathrm{Ar}$ dating constrains the formation of the Inner Basin, an elliptical depression in the center of the volcano initially created by flank collapse. A $530 \mathrm{ka}$ age (with a $\pm 58.4 \mathrm{ka} 2 \sigma$ error) for a post-depression dacite suggests that the collapse event is geochronologically indistinguishable from the termination of the andesitic cone-building activity. According to our DEM analysis, the original cone of San Francisco Mountain had a volume of about $80 \mathrm{~km}^{3}$. Of this volume, $\sim 7.5 \mathrm{~km}^{3}$ was removed by the flank collapse and subsequent glacial erosion, creating the present-day enlarged Inner Basin, and $\sim 2 \mathrm{~km}^{3}$ was removed from the outer valleys by erosion. Based on volumetric analysis and previous and new radiometric ages, the average long-term eruption rate of San Francisco Mountain was $\sim 0.2 \mathrm{~km}^{3} / \mathrm{ka}$, which is a medium rate for long-lived stratovolcanoes. However, according to the new ${ }^{40} \mathrm{Ar} /{ }^{39} \mathrm{Ar}$ dates for the last $\leq 100 \mathrm{ka}$ period, the final stratovolcanic activity was characterized by a greater $\sim 0.3 \mathrm{~km}^{3} / \mathrm{ka}$ rate.

Keywords San Francisco Mountain - DEM analysis . Volcanic geomorphology $\cdot{ }^{40} \mathrm{Ar} /{ }^{39} \mathrm{Ar}$ geochronology . Stratovolcanic activity · Erosion · Colorado Plateau

\section{Introduction: scope and goals}

The stratovolcano of San Francisco Mountain or San Francisco Peaks (SFM hereafter; 3,853 m a.s.l.) is the largest eruptive center of the Late Miocene to Holocene San Francisco Volcanic Field (SFVF, Figs. 1 and 2) in Northern Arizona, USA. Despite last erupting $\sim 0.4 \mathrm{Ma}$ ago according to previous dating on cone-building andesites, the stratovolcano has a well-preserved conical shape except for 


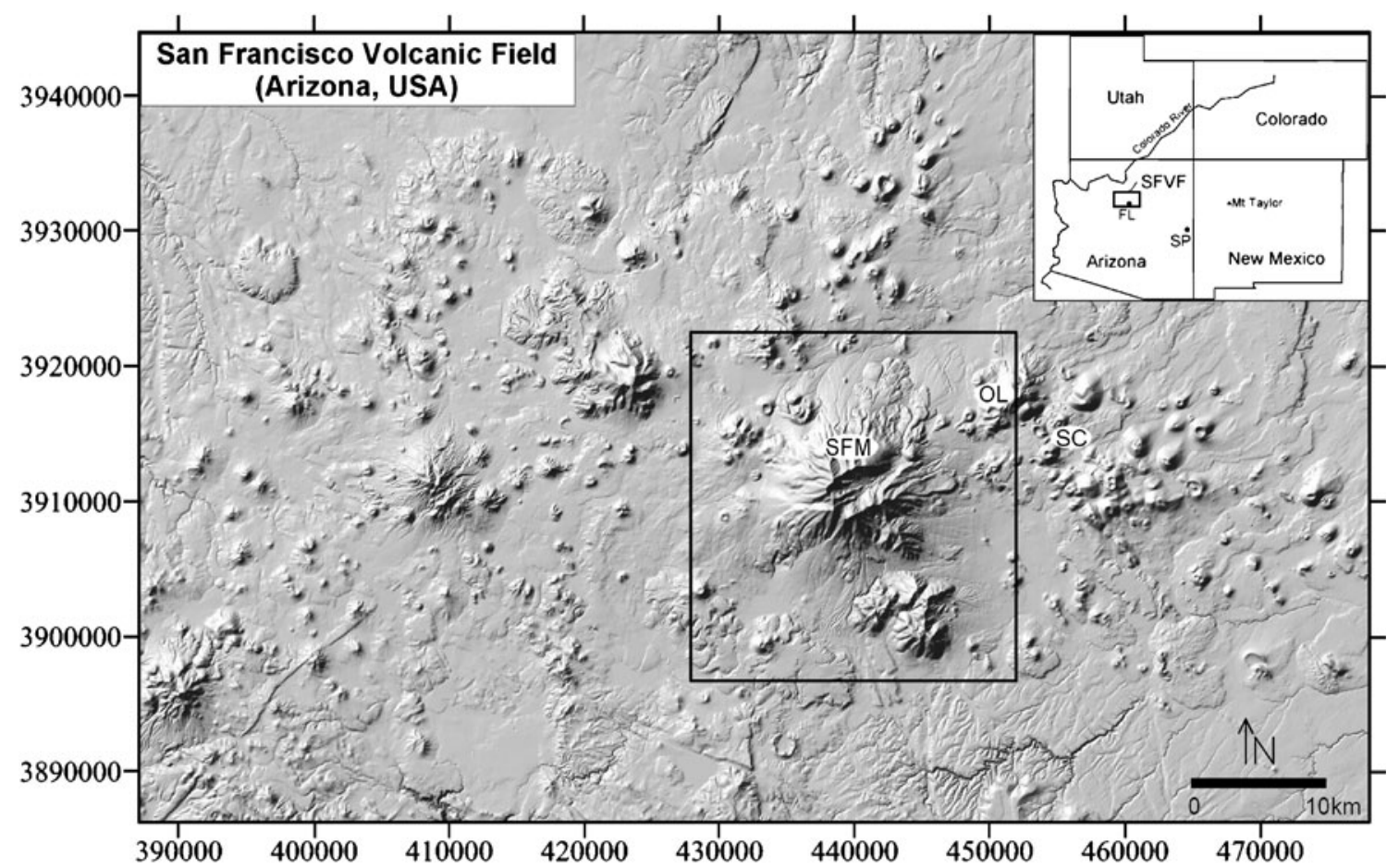

Fig. 1 Location of San Francisco Mountain $(S F M)$ within the San Francisco Volcanic Field ( $S F V F)$. UTM Zone is 12North (WGS84). Quadrangle includes the areas presented in Figs. 3, 4, 5, and 7. Inset map shows location of SFVF in Arizona. (FL Flagstaff, SP Springerville, $O L$ O'Leary Peak, $S C$ Sunset Crater)

nants, the latest configuration of the cone can be reconstructed.

(2) We tie the reconstructed geomorphological elements to previously mapped geological units (Wolfe et al. 1987; Holm 1988). The chronology of the SFM eruptions is known mainly from geologic mapping, relative stratigraphy, $20 \mathrm{~K}-\mathrm{Ar}$ or fission-track determinations and $1{ }^{40} \mathrm{Ar} /{ }^{39} \mathrm{Ar}$ age that range from $2.78 \pm 0.26 \mathrm{Ma}$ to $91 \pm$ $2 \mathrm{ka}$ at the $\pm 2 \sigma$ level of analytical uncertainty (Damon et al. 1974; Wolfe et al. 1987; McKee et al. 1998; Morgan et al. 2004). Here, we use precise ${ }^{40} \mathrm{Ar}{ }^{39} \mathrm{Ar}$ incremental heating methods to better constrain the sequence of late-stage volcanic events.
Fig. 2 View of the Inner Basin from its northwest rim near Humphreys Peak

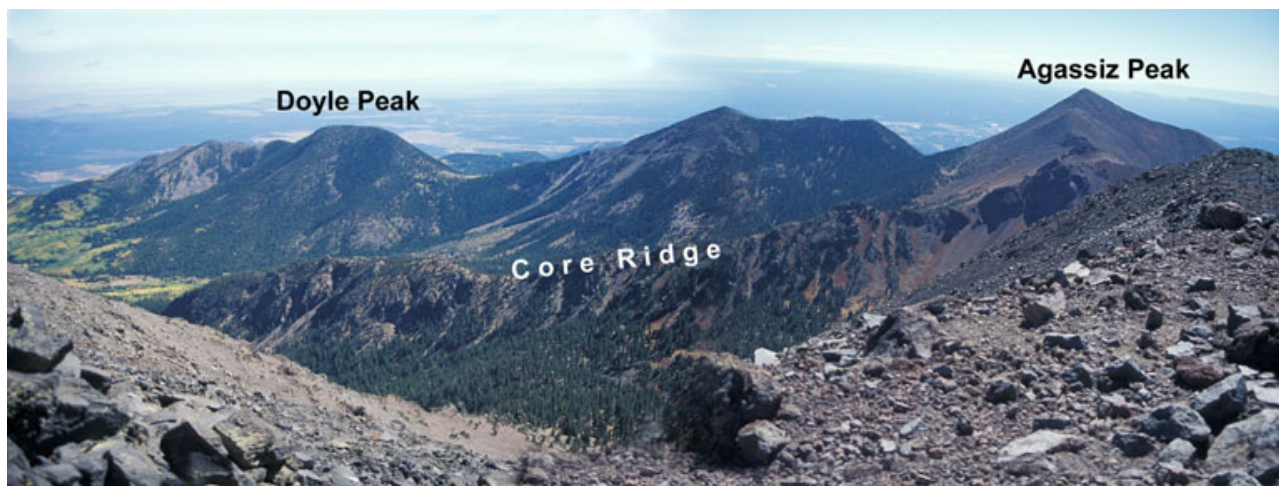




\section{Methods}

Digital elevation model (DEM) applications in geomorphometry are widespread (Burrough and McDonnell 1998), and DEM analysis is occasionally used in studying volcanic areas as well (e.g., Favalli et al. 1999; Székely and Karátson 2004). In our study, we used DEM and DEM derivatives (e.g., slope, aspect, and ridge maps) to quantify the volcanic geomorphology of SFM. The effect of resolution and DEM source on measurements impacts quality of DEM studies (Zhang and Montgomery 1994; Ludwig and Schneider 2006; Wright et al. 2006); our reference DEM was the best available $10 \mathrm{~m}$ spatial resolution US Geological Survey data base.

Constructing shaded relief images, slope and aspect maps are common products derived using GIS software. In order to emphasize the ridge and valley network, several methods (e.g., plan curvature, median difference, modified Hammond method: Hammond 1964; Dikau 1989) could be applied. Here, we used the median difference, in which the elevation difference between each pixel and the median of its $150 \mathrm{~m}$ neighborhood is computed by applying a moving filter. If this difference is greater than a chosen positive threshold, that pixel is classified as a ridge; if it is lower than another chosen negative threshold, it is classified as a valley.

Volumetric calculations of the volcanic edifice and the eroded material have been made by using standard GIS functions that make it possible to determine volumes between two distinct surfaces. For GIS-analysis, we used ESRI ArcView 3.2 and Golden Software Surfer 8 programs.

${ }^{40} \mathrm{Ar} /{ }^{39} \mathrm{Ar}$ ages were determined on groundmass separates from five andesitic and dacitic lava flows (representing the main stratigraphic units of SFM; Table 1) by using furnace incremental heating methods at the University of Wisconsin-Madison Rare Gas Geochronology Laboratory. Sample preparation, mass spectrometry, and data reduction procedures are identical to those of Singer et al. (2008); throughout this paper, ages are reported at the $\pm 2 \sigma$ level of analytical uncertainty relative to $1.194 \mathrm{Ma}$ Alder Creek rhyolite sanidine (Renne et al. 1998) using decay constants of Steiger and Jäger (1977). Isochron analyses revealed that none of the five samples contained significant levels of excess argon, thus the inverse-variance weighted-mean ages, calculated from concordant plateau steps comprising $>80 \%$ of the gas, give the best estimate of time elapsed since eruption (e.g., Singer et al. 2008).

\section{Geological background}

Volcanic evolution

Located in North Central Arizona, SFVF is one of several intracontinental, primarily basaltic volcanic fields

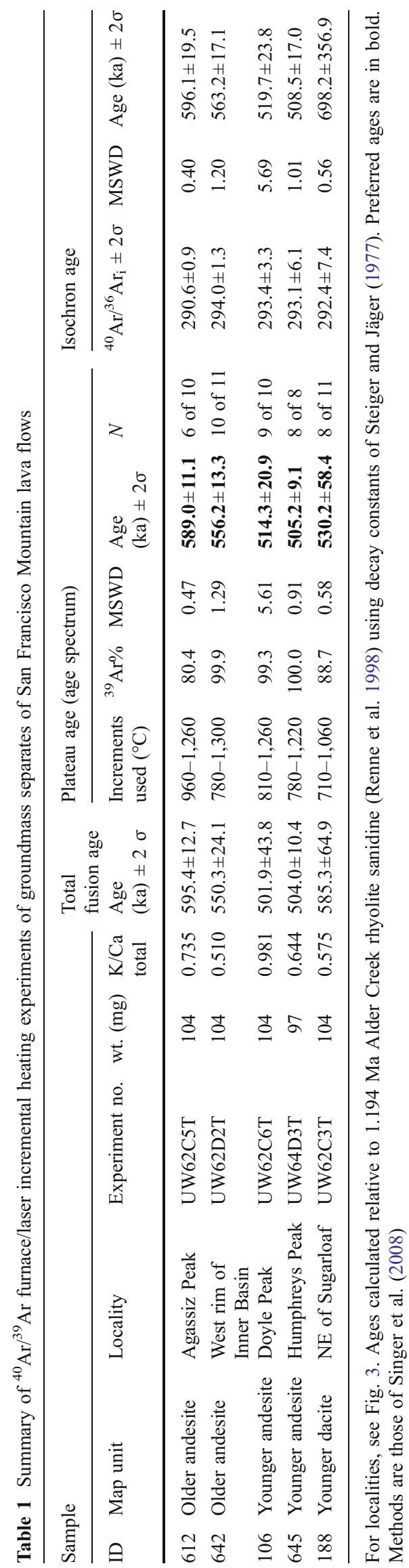


distributed along the southern margin of the Colorado Plateau in Arizona, Utah, and New Mexico. Similar to the other fields (e.g., Mt. Taylor and Springerville Volcanic Fields), it was formed during the latest uplift of the Colorado Plateau (Wood and Baldridge 1990; Parsons and McCarthy 1995). During the volcanic activity, an area of $5,000 \mathrm{~km}^{2}$ of the underlying Permian and Triassic strata, as well as local basaltic sheet flows of late Miocene age, were covered by $\sim 500 \mathrm{~km}^{3}$ of lava and pyroclastic deposits (Wolfe 1984, 1990).

The majority of SFVF consists of alkali basalt lava flows ranging in age from $\sim 6 \mathrm{Ma}$ to $1 \mathrm{ka}$ that erupted from more than 600 vents, most of which are marked by scoria cones (Wolfe 1990). In addition to other vents that produced local eruptions of basaltic andesite, andesite, dacite, rhyolite, benmoreite, and trachyte (Moore and Wolfe 1987; Newhall et al. 1987; Wolfe et al. 1987), SFVF includes five longlived composite volcanoes consisting of andesite, dacite, and rhyolite. SFM volcano is the largest of these edifices (Wolfe et al. 1987; Holm 1988).

The growth of SFM stratovolcano (Fig. 3) was dominated by regional extension with northeast-southwest orientation of the minimum principal tectonic stress axis (Holm 2004; Morgan et al. 2004). This stress orientation also determines the location of several monogenetic centers east of SFM, including Sunset Crater, site of the most recent activity in the SFVF (1064-1065 AD, Smiley 1958; Moore and Wolfe 1987; Holm and Moore 1987). SFM was built mostly by effusive activity producing andesites (85\%), dacites (12\%), and rhyolites (1\%; Holm 1987). These rocks display a continuous compositional succession from low-Si andesites to alkali rhyolites (Holm 1988, 2004) that were arranged in three main stages, each showing an evolution from dacite and rhyolite lava domes to andesite lava flows. Dacite and rhyolite lava domes erupted both in the central and peripheral parts of the stratovolcano, whereas most andesite lava flows erupted from central vents. Specifically, a dacite summit dome of SFM at the end of stage 3 was inferred from borehole analysis (Holm 2004). Finally, a minor fourth stage produced peripheral dacite and rhyolite domes and a small andesite flow.

The central location of the main andesite vents is supported by a general radial arrangement of dikes that however may have also fed flank vents (Holm 1988, 2004). These vents as well as the upper cone including possible craters and summit domes have been completely eroded, and now the center of the volcano is occupied by the elongated depression called the Inner Basin. A number of dikes exposed within the Inner Basin are found at Core Ridge (Figs. 2 and 3), a radial ridge dividing the Inner Basin into two embayments.

Previous radiometric datings show that the eruptive activity in the region of SFM took place between 2.8 and
$0.1 \mathrm{Ma}$, interrupted by long repose periods (Damon et al. 1974; Wolfe et al. 1987; McKee et al. 1998; Morgan et al. 2004). The andesitic stratovolcano of SFM may have been formed between 0.9 and $0.4 \mathrm{Ma}$ (McKee et al. 1998). Out of the three main eruptive stages distinguished by Holm (2004), primarily the stage 2 and 3 cone-building stages, the so-called "Older Andesites" (Holm 1988) with 0.7$0.8 \mathrm{Ma}$ and "Younger Andesites" with $~ 0.4-0.5 \mathrm{Ma} \mathrm{K}-\mathrm{Ar}$ ages (Wolfe et al. 1987), control the present morphology of the stratovolcanic cone. According to Holm (1987), these two stages enlarged the cone to $\sim 110 \mathrm{~km}^{3}$ based on stratigraphy and topography. The youngest product of the volcano subsequent to the main andesitic-dacitic stratovolcanic evolution is Sugarloaf rhyolite dome; a previous $\mathrm{K} / \mathrm{Ar}$ age $(220 \pm 40 \mathrm{ka}$ by Damon et al. 1974) was proven to be too old by a recent ${ }^{40} \mathrm{Ar} /{ }^{39} \mathrm{Ar}$ dating $(91 \pm 2 \mathrm{ka}$, Morgan et al. 2004).

On the basis of geologic mapping (Holm 1988), the Older Andesites (Fig. 3) constitute mainly the west part of the volcano (vicinity of Agassiz Peak and west rim of the Inner Basin) and most of the lower slopes of the north wall of the Inner Basin. Occasionally, they can be found at the north, northeast, and east foot of the volcano. The Younger Andesites are present on all flanks of the volcano; specifically, there is a large, well-defined lava flow series on the west flank of Agassiz Peak (Fig. 3). Dacites (that are related in time both to Older and Younger Andesites) can be found on all slopes of the volcano, principally on the lower flanks; in addition, they occur in some places on the southern rim of the Inner Basin (Fig. 3). A stratigraphically important, young dacite flow, called Lockett Meadow dacite (Fig. 3) is interpreted to be post-Inner Basin age by Holm (2004). It originated from around Reese Peak (Fig. 3) and lies on debris-flow deposits that appear to be part of the northeast debris fan deposited during the formation and/or subsequent erosion processes of the Inner Basin. If this interpretation is correct, then the age of this flow gives a minimum date for the formation of the Inner Basin. Of the small patches of rhyolites, the most pronounced is the above-mentioned, 91 ka Sugarloaf dome (Fig. 3), which was emplaced in the outlet of the Inner Basin but much later than the formation of the basin.

Unsolved problems of cone evolution

Despite accurate geologic mapping, the original constitution of the volcanic cone and formation of its present morphology are still debated. The creation of the Inner Basin and its rim $(\sim 3,200-3,500 \mathrm{~m}$ high $)$ has been explained by different ideas from an earlier hypothesis of erosion caldera formation (Robinson 1913) through intense glacial erosion (Updike 1977) to modern sector-collapserelated explanations (Holm 1988, 2004; Duffield 1997). 
Fig. 3 Simplified geologic map of SFM (after Holm 1988) draped on the $30 \mathrm{~m}$ USGS DEM. Red outline marks the boundary of the stratovolcano based on geology and DEM interpretation. Some Older Andesite lava flows to the north beyond the volcano's base are not shown. Younger Andesite lava flows to the south are partly covered by lava flows from other volcanoes. Numbers show the locations of samples used for ${ }^{40} \mathrm{Ar} /{ }^{39} \mathrm{Ar}$ dating (Table 1 ). This map is to help identify units mentioned in the text; for simplicity, some categories (such as Core Ridge, Older Dacites,

Younger Dacites, and Rhyolites) are stratigraphically compound, consisting of different-aged rocks each. Surficial deposits include Pleistocene and Holocene alluvium, colluvium, talus, till, and debris-flow deposits

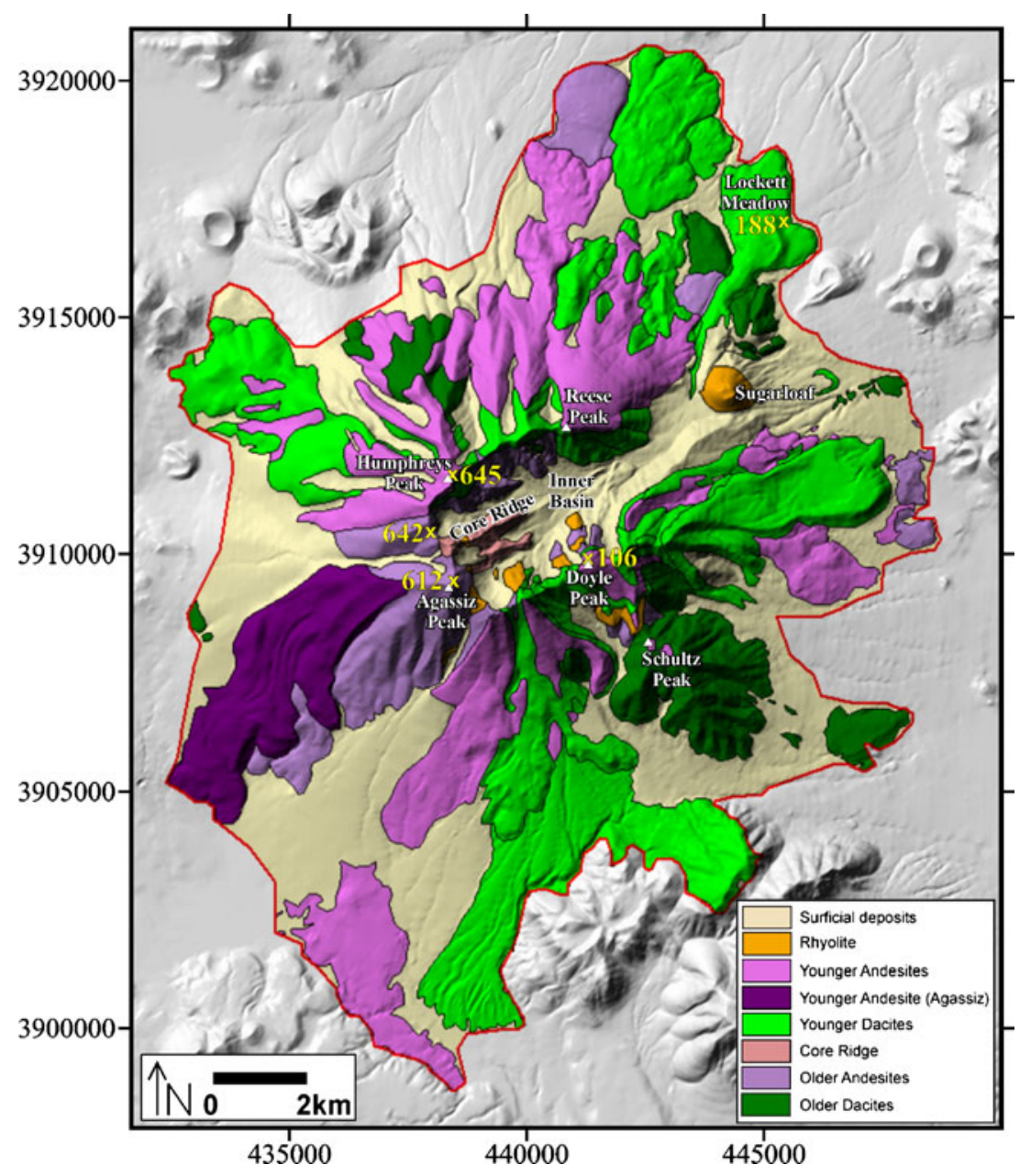

According to the latter authors, toward the end of cone evolution, large sector collapses occurred to the NE. Unfortunately, no debris avalanche deposits have been preserved, but they may be present at $\sim 350-400 \mathrm{~m}$ depth according to the analysis of a borehole NE of the Inner Basin (Holm 2004). The elongated Inner Basin, the aligned centers of O'Leary Peak (Fig. 1), Sugarloaf, and SFM, as well as some of the longest dikes of Core Ridge (Holm 2004), and a well-defined magnetic low, are all colinear and thus may have formed under the influence of a common structural control (Tanaka et al. 1986; Wolfe 1990).

The orientation and the half-open mouth of the Inner Basin are in accordance with its primarily sector collapse origin. On the other hand, at least a part of its present shape can be attributed to glacial resculpturing. The depression hosted a number of glaciers (Updike 1977) whose cirque walls and moraines are still visible. Due to the obvious post-collapse erosion, Holm (2004) considered the Inner Basin as an "erosion caldera," although it lacks the typical fluvial erosional dissection and modification defined for erosion calderas by Karátson et al. (1999). However, the contribution of erosional modification as well as the role of glacial vs fluvial erosion in forming the present-day Inner Basin has not been clarified.

Another unresolved problem is the original summit morphology of the stratocone. Holm $(1987,2004)$, assuming a point-like summit, reconstructed a $4,700 \mathrm{~m}$ highest (pre-collapse) elevation for the volcano. According to Holm's reconstruction, this volcano (corresponding to the Younger Andesites) may have superposed an older cone (of Older Andesites) with unknown elevation. A more precise configuration (i.e., positions, heights) of these landforms as well as precise age constraints distinguishing the Older and Younger Andesites were not presented.

\section{Results}

Cone volume and cone-building lava flows

SFM has a complex but relatively regular cone shape that resulted from the superposition mostly of lava flows. The surficial area of the present cone has been delimited using the geologic map with smaller refinements from the DEM 
analysis (Figs. 3 and 4). The cone base is positioned from 2,500 to 2,100 $\mathrm{m}$ a.s.l. from $\mathrm{W}$ to $\mathrm{E}$ and from $\mathrm{N}$ to $\mathrm{S}$; it largely corresponds to less than or equal to six degree slopes, although a number of lava flows overran the boundaries. These elevation data indicate the earliest andesites of SFM (underlain by unrelated Pliocene basaltic rocks; Holm 1988). Therefore, we calculated the central cone volume by using a generalized base level at the average 2,300 $\mathrm{m}$ (a.s.1.).

Based on our DEM analysis, the actual volume of SFM above the boundary is $70.5 \mathrm{~km}^{3}$. Every further 50 -m-thick underlying basalt/basaltic andesite or intrusive substrate would give an $\sim 10 \mathrm{~km}^{3}$ increase in volume, i.e., the error of $\pm 50 \mathrm{~m}$ base level is $\pm 15 \%$ in terms of volume.

At present, the overall morphology of the cone reveals an eroded, degraded surface rather than the original lavaflow surfaces. However, delineation of lava flows on the lower slopes is possible in many cases with the help of DEM-derived shaded relief images and especially slope maps (Fig. 4). We consider a linear, tongue-shaped form with steep scarps and an orientation radial from center of the cone to be a remnant of an original lava flow. The result of lava flow delimitation (Fig. 4a) is certainly in accordance with the geologic map (Holm 1988), but makes further refinements possible. Sometimes, even the original lobes and flow structures (e.g., pressure ridges) of individual flows can be reconstructed. This is the case with Agassiz Peak lava flows (Fig. 4a), where the geologic map indicates a large undifferentiated lava flow: on the basis of the slope map, a number of individual flow units can be delimited, and even the approximate position of their source can be inferred. Some dacite lava flows (e.g., on the north slopes) are even more pronounced than andesite flows. The huge dacite flow east of Doyle Peak (Fig. 3) seems to have a source not at Doyle Peak (i.e., on the southern rim) but inside the Inner Basin. Similarly, dacite flow lobes southwest of Doyle Peak and those north of Reese Peak (Fig. 4a) point to the central part of the Inner Basin. This way, slope map analysis gives a rough indication for locating the eruption center.

Reconstructing the original volcanic cone

As suggested by earlier workers, the present-day volcano is but a remnant of an original cone of SFM (e.g., Holm 1988, 2004). Detailed analysis of DEM, with the help of new ${ }^{40} \mathrm{Ar} /{ }^{39} \mathrm{Ar}$ ages, allows us to precisely reconstruct the original volcanic landform and date its cone-building activity.

Planèze analysis Under semihumid to dry climates, remnants of original cone surfaces may be found as planèzes or flatirons (Ollier 1988; Karátson et al. 1999). These are polygonal, preferably triangular flank segments that remain relatively undissected between the pathways of fluvial (or glacial) erosion (Cotton 1952; Ollier 1988). Although wet climates (i.e., high valley density and rapid cone erosion) may obliterate planèzes in a short time, fortunately the relatively high precipitation at San Francisco Mountain has been snow rather than rain. Today, there is only $600 \mathrm{~mm}$ of annual rainfall and more than $2,000 \mathrm{~mm}$ of snow in Flagstaff (S foot of the mountain). During Ice Ages, higher precipitation fed glaciers and only minor fluvial erosion may have occurred; also, during the interglacials and in the

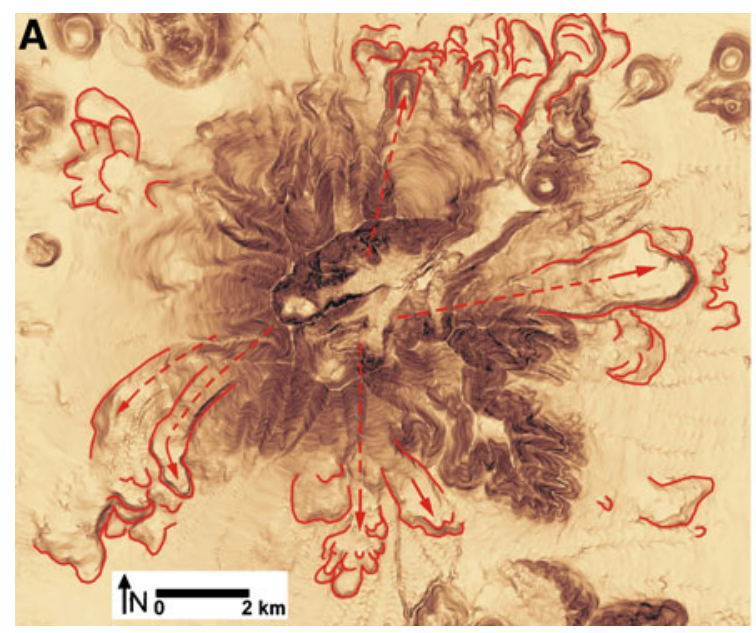

Fig. 4 a Slope map of SFM showing results of lava flow delimitation and some indications to possible vent regions (red arrows and dotted lines). b Slope category map of SFM: 1-flat or gently dipping surfaces of glacial valley bottom and volcanic apron (including surfaces of distal lava flows), 2-gentle slopes of lower flanks of

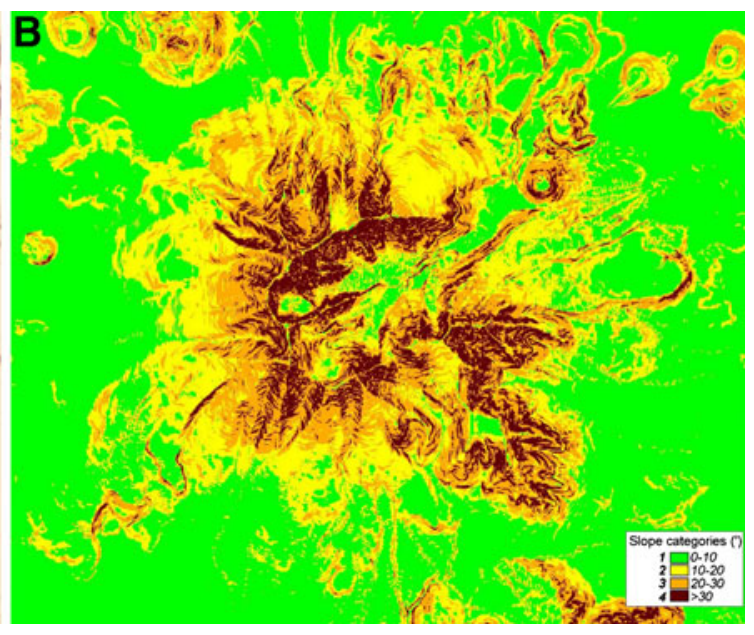

volcanic cone including planèzes, 3 -moderate slopes of lower to middle volcano flanks, 4-steep slopes of middle to upper flanks affected by glacial erosion (e.g., cirque walls) and original (volcanic) surfaces of parasitic cones and lava flow scarps 
Fig. 5 Ridge map of SFM. Red: ridges, blue: valleys; color scale values show the elevation difference of the actual pixel and the median of its $150 \mathrm{~m}$ neighborhood. Quadrangles of $A$ and $B$ correspond to extract maps in Fig. 6

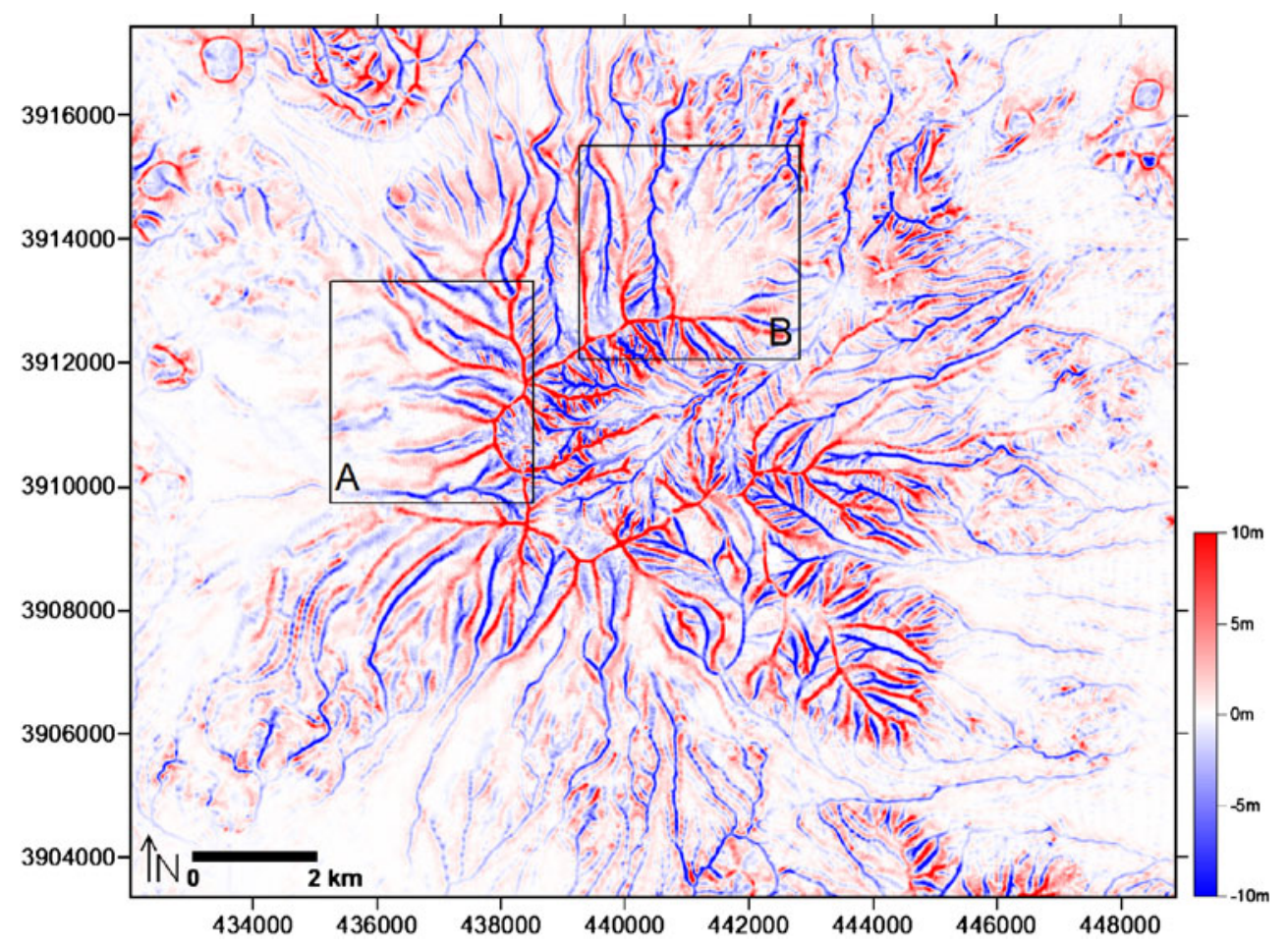

Holocene, the high altitude of the volcano has promoted periglacial rather than fluvial processes (e.g., Updike 1977). Thus, some planèze landforms are expected to have survived (i.e., remained undissected) in spite of the relatively old age of the cone surface.

We delimited planèzes on slope and ridge maps (Figs. 5 and 6) as widening flank segments of largely uniform slope without valley or ridge landforms. In Fig. 6, examples of planèze delimitation are shown. Of them, the most intact planèze is that of Reese Peak formed on Young Andesite of the northeast flank. After selecting the planèzes (Fig. 6), we connected them to the Older and Younger Andesites, respectively, supposing that these latter indeed represent two geomorphologically and geochronologically distinct groups. (Some small planèzes of dacite lavas have not been considered due to uncertainties of their origin and age). Then, we fit circles to all planèzes in each planèze group through as many same elevation points as possible (Fig. 7, Table 2).

As far as the reliability of such a planèze reconstruction is concerned, first we emphasize that our approach is based on the assumption that each planèze group determines a regular, symmetrical upper cone. Second, assuming that a given elevation point on the planèze surface differs vertically with $d h$ from the ideal cone suface (e.g., due to a lava flow of unknown thickness, which gives an error to the calculation), the horizontal distance from the ideal cone surface will be $d h / \tan \alpha$ if the planèze around the selected
Fig. 6 Planèzes (roughly triangular surfaces on original cone surface) on the west and northeast flanks of SFM. Red: ridges, blue: valleys
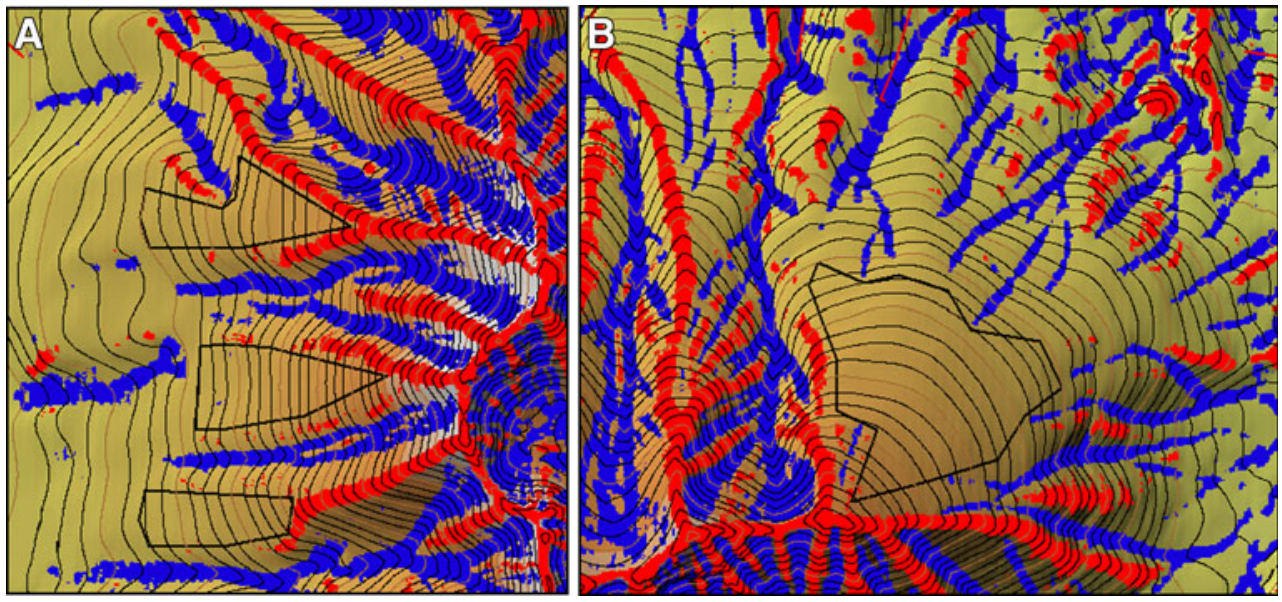


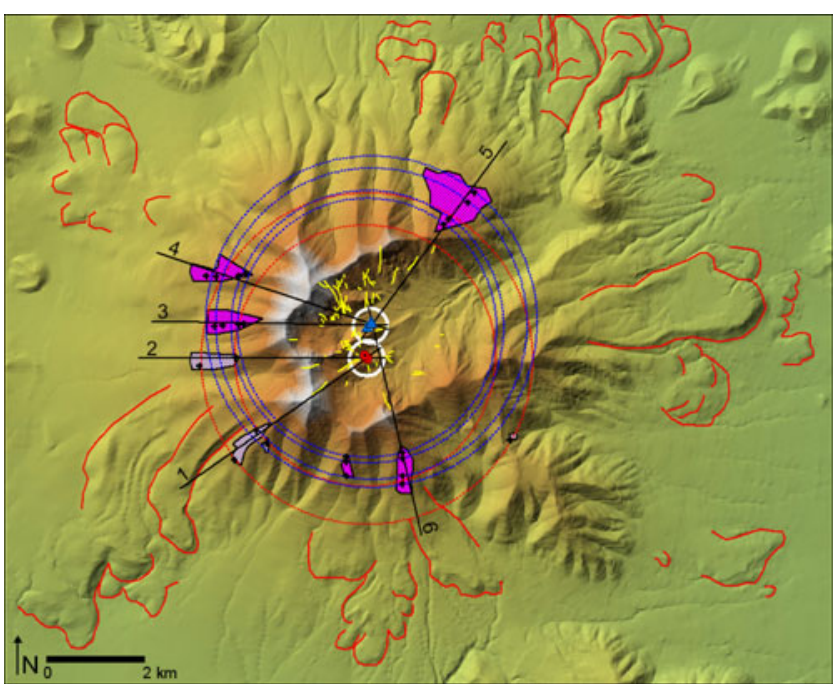

Fig. 7 Fitted circles on planèze remnants according to lava flow stratigraphy: the red and blue circles correspond to Older and Younger Andesites, respectively. The centers of the circles, i.e., geometric positions of original vent regions, are indicated, respectively, by blue triangles and red dots. White circles indicate 700-m-wide vent regions. The red dots plot on diorite plugs mapped as principal conduit for the Older Andesites, whereas the blue triangles plot on a large (1,080-m long) dike of monzodiorite that supplied the Younger Andesites (Holm 1988). Arrangement of dikes in the Inner Basin is after Holm (1988). Black lines and numbers refer to positions of topographic profiles in Fig. 8

point has a radial slope $\alpha$. Provided the planèzes are distributed roughly evenly (i.e., all around the cone and not in a specific sector), we can get their "average" center by fitting circles to their same elevated points. "Average" means that, this way, the horizontal error $(d l)$ of the center relative to the ideal center will be the averaged error of fitting planèze points, that is, the horizontal error of a given point will be divided by $n$ to calculate its effect on the horizontal error of the center, where $n$ is the number of planèze points used to fit a given circle. Illustrated by an example, if a circle (i.e., a reconstructed contour) is determined by three points (on three differently located planèze surfaces), and we assume a 50-m-vertical error (i.e., a lava flow) and $20^{\circ}$ slope of planèze at the given point, then we will get a 46-m-horizontal error with respect to the calculated center.

$$
\left(d l=\frac{d h}{n \cdot \tan \alpha}=\frac{50 m}{3 \cdot \tan 20^{\circ}}=46 m\right)
$$

In fact, the geometric centers of the two fitted circle series determine two centers of possibly two upper cones. Those of the Older Andesites are shown in red circles and those of Younger Andesites are in blue triangles. The northern cone is determined by five planèzes distributed roughly evenly around the cone using four to five fitting points per circle. Their centers are located within a circle with $80 \mathrm{~m}$ radius. The horizontal error between the fitted points and fitted circles on planèze surfaces (Table 2) may differ up to $150-180 \mathrm{~m}$, but in most cases, it is less than $30 \mathrm{~m}$. The southern cone has only three points per circle, and two fitted circles along three planèzes and a point-like spur on the SE flank, which are unevenly distributed (because the north flank became covered subsequently by Younger Andesites). Therefore, the uncertainty can be considered larger, nevertheless the distance between the two resulting centers is only $75 \mathrm{~m}$.

The projected centers of both cones fall within the Inner Basin. The circumscribed white circles correspond to possible vent regions (large crater(s) and/or summit lava domes) with an ideal $700 \mathrm{~m}$ diameter each, i.e., a minimum size of broad summit at many present-day active volcanoes (e.g., Wood 1978). The two projected vent regions happen to plot, respectively, on diorite and monzodiorite intrusions, that were considered as principal conduits of the Older and Younger Andesite (Holm 1988, 2004).

Maximum elevation of both reconstructed cones was calculated by elevation profile analysis. Fig. 7 shows the position of elevation profiles through planèzes, whereas the

Table 2 Results of cone circle fitting to planèze points

\begin{tabular}{|c|c|c|c|c|c|c|c|c|c|c|c|c|}
\hline \multirow[t]{2}{*}{ Circle (as in Fig.7) } & \multirow[t]{2}{*}{ Fitted Points Elevation (m) } & \multicolumn{2}{|c|}{ Center Coordinates } & \multicolumn{9}{|c|}{ Distance $(\mathrm{m})$ of fitting point to the fitted circle at different planèzes } \\
\hline & & Easting & Northing & $O, W$ & $O, S W, L$ & $O, S W, S$ & $O, S E$ & $Y, W N W$ & $Y, W$ & $Y, S, S$ & $Y, S, L$ & $Y, N E$ \\
\hline Red Large & 2,990 & 439559 & 3910261 & 21 & 7 & & 26 & & & & & \\
\hline Red Small & 3,240 & 439523 & 3910322 & 23 & 25 & 22 & & & & & & \\
\hline Blue Largest & 3,075 & 439569 & 3910907 & & & & & 112 & 188 & & 24 & 3 \\
\hline Blue Larger & 3,135 & 439560 & 3910889 & & & & & 126 & 161 & 39 & 20 & 14 \\
\hline Blue Smaller & 3,275 & 439650 & 3911012 & & & & & 40 & 156 & 4 & 2 & 5 \\
\hline Blue Smallest & 3,320 & 439650 & 3910970 & & & & & 67 & 134 & 12 & 6 & 11 \\
\hline
\end{tabular}

Circle names are according to Fig. 7. Center coordinates are in UTM projection

$O$ Older Andesite planèze, $Y$ Younger Andesite planèze; $W, S W, W N W, W, S$, and $N W$ azimuthal directions; $S$ small planèze, $L$ large planèze 
profiles (four for Younger Andesites and two for Older Andesites) are presented in Fig. 8. The method we followed is to complete the upper cone by using a concave-upward (parabolic) elevation profile reaching $30^{\circ}$ slope at the summit, which is the typical steepest slope of stratovolcanoes (Wood 1978; Davidson and De Silva 2000). The profiles are truncated by a broad summit of $700 \mathrm{~m}$ diameter. The obtained profiles result in different elevations for the two cones: average summit elevation of the Younger Andesite cone is $4,460 \mathrm{~m}(4,492,4,475,4,415$, and
4,460 m), while average summit elevation of the Older Andesite cone is $4,350 \mathrm{~m}(4,311$ and $4,388 \mathrm{~m})$. (These absolute elevations correspond to $\sim 2,160$ and $\sim 2,050 \mathrm{~m}$ relative cone heights, respectively). Assessment of the proposed original summit configuration, with respect to temporal evolution, is given in the discussion.

In order to determine the original volume of the cone, we constructed a new DEM in which all valleys were infilled up to the level of the dividing ridges. Starting from the ridge map (Fig. 5), the infilling was made by connecting the
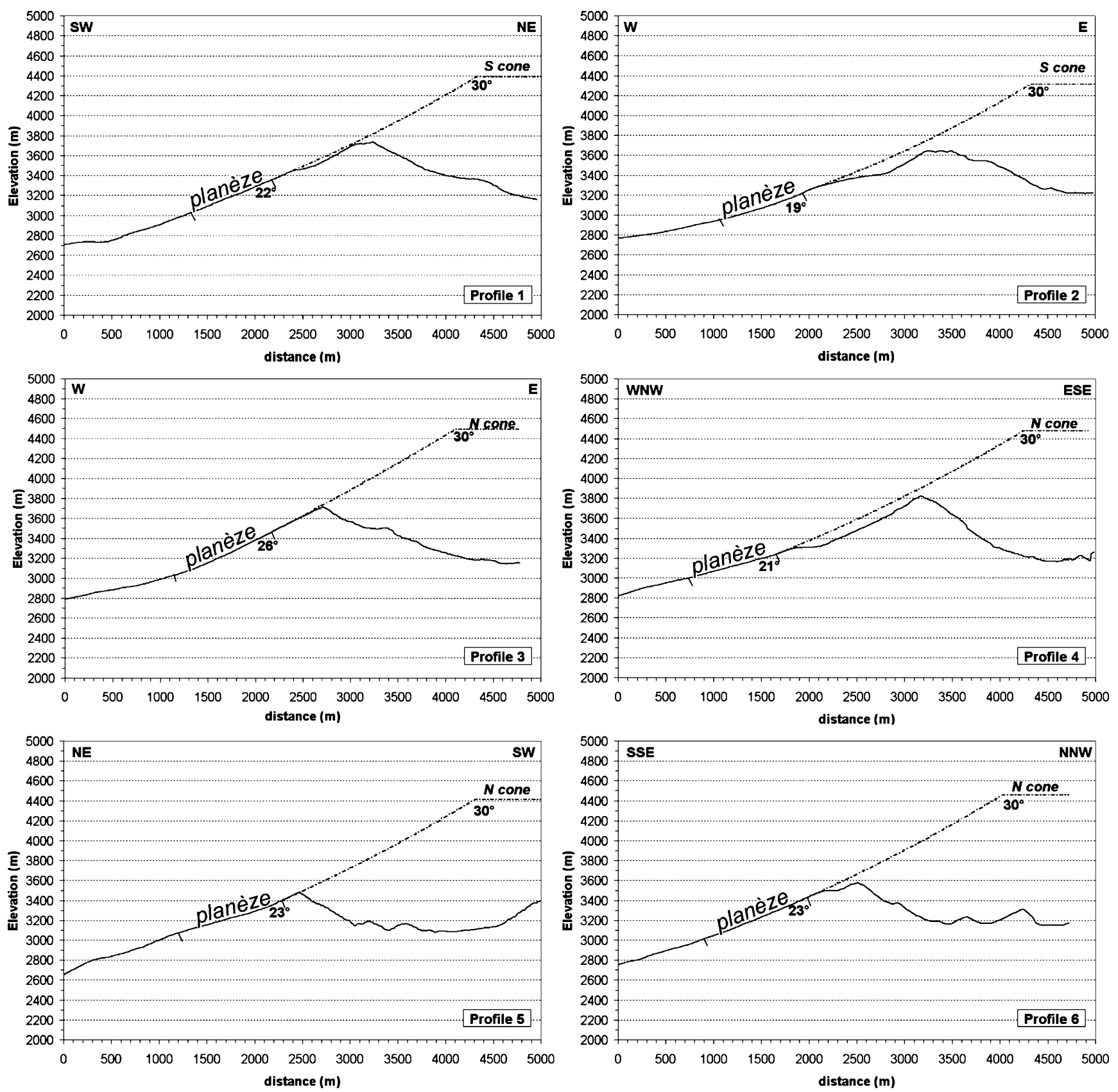

Fig. 8 Representative profiles using planèze surfaces of SFM and ideal (parabolic, concave-upward) stratovolcano slopes gradually increasing to $30^{\circ}$, truncated by a 700 -m-wide summit (see text). For profile locations, see Fig. 7 
ridges by the Natural Neighbor interpolation method of Surfer 8 software. The volume difference between the infilled cone and the present cone is $4.5 \mathrm{~km}^{3}$, which may have resulted primarily from glacial and subordinately from fluvial erosion. (Of this volume, $2.7 \mathrm{~km}^{3}$ falls within the Inner Basin, and $1.8 \mathrm{~km}^{3}$ within the outer valleys). The volume difference between the infilled cone surface and the reconstructed original cone surface is $4.9 \mathrm{~km}^{3}$, which is the result of the disappearance of the upper cone mostly due to the flank failure. This way, the original volume of SFM might have been $70.5+4.9+4.5=79.9 \mathrm{~km}^{3}$. This figure is significantly smaller than the previous estimate of $110 \mathrm{~km}^{3}$ by Holm (1987).

${ }^{40} \mathrm{Ar}{ }^{{ }^{9}} \mathrm{Ar}$ geochronology In order to geochronologically constrain the cone-building volcanic activity, four andesitic lavas and one dacitic lava in key positions were dated (for sample locations see Fig. 3). The andesitic samples (two each from Older and Younger Andesites) originate from the highest point of the rim of the Inner Basin, and for stratigraphic reasons are expected to reflect the latest effusive periods within each andesite group. The sampled dacitic lava is from Lockett Meadow dacite that is supposed to postdate the formation of the Inner Basin.

The ${ }^{40} \mathrm{Ar} /{ }^{39} \mathrm{Ar}$ plateau age determinations of the selected samples range from $589 \pm 11$ to $505 \pm 9 \mathrm{ka}$ (Table 1). The age spectra are concordant with $>80 \%$ of the gas comprising the age plateau for each sample. Sample 106, however, yields a weakly saddle-shaped spectrum with a single step comprising $10 \%$ of the gas that gives an age slightly lower than the mean age, thereby increasing the mean squared weighted deviate to greater than five (Table 1). Despite this, the plateau age for this sample is consistent with those of the other samples, thus we accept it as the eruption age.

The new ${ }^{40} \mathrm{Ar} /{ }^{39} \mathrm{Ar}$ age determinations of the andesitic cone-building activity coincide with the field-based stratigraphic division. The Older Andesites gave ages of $589 \pm 11$ and $556 \pm 13 \mathrm{Ma}$, while the Younger Andesites $514 \pm 21$ and $505 \pm 9$ Ma. The $589 \pm 11 \mathrm{ka}$ age of the Older Andesite on Agassiz Peak is younger than a previously reported K-Ar age of $660 \pm 160 \mathrm{ka}$ (also with $\pm 2 \sigma$ analytical error, i.e., big uncertainty) obtained at the northern side of the peak (McKee et al. 1998). In contrast, the new $505 \pm 9$ ka age of the Younger Andesite on Humphreys Peak (the youngest lava flow apparently truncated by the collapse) is older than the previously reported $430 \pm 60 \mathrm{ka} \mathrm{K}-\mathrm{Ar}$ age of the same flow (McKee et al. 1998) and defines the termination of the andesitic volcanism. This way, according to the new ages, the two andesitic stages represent a much shorter final cone-building activity $(<100 \mathrm{ka})$ than suggested by previous work (i.e., 0.8-0.4 Ma).

The ${ }^{40} \mathrm{Ar} /{ }^{39} \mathrm{Ar}$ age of the dated dacite is $530 \pm 58 \mathrm{ka}$. It significantly improves a previous dating that gave $410 \pm$
$320 \mathrm{ka}$ (Damon et al. 1974) for the same dacite (on the east flank of Reese Peak). The obtained new age is not definitely younger than the latest andesites, but with respect to its relatively big analytical uncertainty, it is indistinguishable from the $514 \pm 21$ and $505 \pm 9$ ka Younger Andesites. Given the assumption of being post-Inner Basin, the age of the dacite would place the collapse and formation of "proto"-Inner Basin at $530 \pm 58 \mathrm{ka}$, but the eruption of the youngest andesite $(505 \mathrm{ka})$ and its error $( \pm 9 \mathrm{ka})$ suggest a more likely post-514 ka age. Anyway, the obtained ages of Younger Andesite and Lockett Meadow dacite are consistent with a rapid series of volcanic and collapse events at $\sim 530-505 \mathrm{ka}$.

\section{Discussion}

The DEM analysis allowed us to restore the adjacent stage 2 and 3 cones of SFM. Our results imply that the lower flanks of both cones are represented in the actual relief, in spite of the late-stage collapse and subsequent erosion of the cone.

The method we applied, however, started from the assumption that both cones had perfect, symmetric morphology. We should also consider the possibility of other configurations, above all a less regular morphology of a single upper cone and crater. A (long-lived) stratovolcano may erupt lavas that overflow at the lowest point on the crater rim, which becomes higher by the end of the eruption, and the next time the lava flows down a different flank. Hence, as the volcano grows, the lava flows gradually and alternately cover all flanks. With regard to our reconstruction, this scenario raises the alternative that the Older and Younger Andesites at SFM may have come from different sides of the same crater (or vent region).

The centers of Older and Younger Andesites are $<1 \mathrm{~km}$ from each other. Their respective center points obtained from the fitted circles are not scattered, but grouped in two limited areas, making the existence of two vents more likely than two points on opposed rims. However, their distance is not large enough to exclude a single crater that issued lava flows to different directions. To address this question, first we discuss the chronology of the two andesite groups.

The new ${ }^{40} \mathrm{Ar} /{ }^{39} \mathrm{Ar}$ ages support the distinction between the Older and Younger Andesites. The two dated andesites of each unit are arranged in subsequent order, and may have been separated by a dormant period (within analytical uncertainty). According to the new data, the eruptive center of the Older Andesites is $\sim 30-50$ ka older than that of the Younger Andesites. Based on our elevation profile analysis, the elevation of the eruptive center of the Older Andesites was $4,350 \mathrm{~m}$. The time span between eruption of the Older 
and Younger Andesites, assuming erosion during a dormant period, argues for a considerable degradation of the older vent (crater) by the time the eruptions of Younger Andesites began. Thus, eruption of the Younger Andesites may have begun from a center below 4,350 m a.s.l. Distribution of the Younger Andesites argues against the alternative configuration (i.e., eruption of both the Older and Younger Andesites from opposite sides of a single large crater). Given that their projected center is a small dot in the north, it would be difficult to explain how the southerly lavas flowed from the northern single rim. Therefore, it is more logical to assume that the Younger Andesites erupted from a vent shifted slightly to the north, then buried the eroded vent of the Older Andesites. Alternatively, a part of the Younger Andesites may have come from fissure vents on the south flanks. Based on our elevation analysis the younger vent eventually achieved an elevation of 4,460 m.

In summary, we do not have definitive evidence for the original configuration of the crater region, but the andesite stratigraphy, established by geologic mapping, fits well with the planèze analyis and ${ }^{40} \mathrm{Ar} /{ }^{39} \mathrm{Ar}$ chronology, and therefore we consider our hypothesis as the most likely scenario. Our proposed two-cone model, showing the adjacent cones as idealized geometric forms, is presented in Fig. 9. In order to emphasize the subsequence of cones in time, the reconstructed stage 3 (north) cone at the end of Younger Andesite activity and then by that time eroded (possibly covered) remnants of stage 2 (south) cone are depicted.

The further erosional history of the central part of SFM, i.e., the enlargement of the Inner Basin after collapse of the upper cones, seems to be governed by Core Ridge. Based on its geologic mapping (Holm 1988), Core Ridge represents an emergent part of the initial stratovolcano. Subsequently, it was buried by the stage 2 and 3 upper cones and interlaced and strengthened by their feeder dikes and intrusions as well as propylitic alteration (Wolfe et al. 1987; Holm 1988). After the collapse that destroyed a significant portion of both cones, the exhumed, resistant rocks of Core Ridge may have controlled the location of glacial erosion. At present, the west part of the Inner Basin contains two cirques north and south of Core Ridge (Fig. 2) that fed considerable glaciers (Updike 1977, see below). These cirques may have formed in the less resistant basal portion of stage 2 and 3 cones, whereas in between, Core Ridge became progressively more exhumed. Glacial erosion occurred during the Illinoian (most extensive) and Wisconsin glacier advances (from $\sim 300$ to $20 \mathrm{ka}$ : Updike 1977; Bezy 2003), which, however, may have overprinted the record of older glacials (pre-Illinoian B and A, from 450 to $300 \mathrm{ka}$ : Ehlers and Gibbard 2004; Gibbard et al. 2007).
Subsequent to glaciation, only minimal fluvial erosion has occurred, as testified by the slope category map (Fig. 4b) and topographic sections through the Inner Basin (Fig. 10) that unequivocally show a flat bottom of glacial origin. Typical slope angles at SFM can be divided into four categories (Fig. 4b), and one of these, category 1, is associated with (a) flat bottom of cirques and glacial valleys and (b) ring plain (of volcaniclastic and fluvial apron). A flat interior is absent in fluvially modified erosion calderas where a dendritic drainage pattern has usually developed (Karátson et al. 1999). These erosion calderas are typically much older (e.g., the 1.5 Ma Mt. Taylor in New Mexico: Perry et al. 1990; Love and Connell 2005; for other examples, see Karátson et al. 1999). At SFM, dominance of glacial resculpturing over fluvial erosion is also shown by the broad outlet of the Inner Basin (Figs. 2, 3, and 4), a feature that never appears in real erosion calderas (Ollier 1988; Karátson 1996; Karátson et al. 1999).

Finally, the growth rates of SFM are addressed using the volumetric reconstruction of the original cone and new radiometric dates. The reconstructed volume of SFM is $80 \mathrm{~km}^{3}$, and its lifetime is $\leq 400 \mathrm{ka}$. Therefore, the timeaveraged eruptive flux of SFM is $0.2 \mathrm{~km}^{3} / \mathrm{ka}$. This rate is similar to that obtained for a number of stratovolcanic complexes such as Volcán Tatara, Chile $\left(0.24 \mathrm{~km}^{3} / \mathrm{ka}\right.$ : Singer et al. 1997), Mt. Adams, OR, USA (stratocone, $0.38 \mathrm{~km}^{3} / \mathrm{ka}$; volcanic field, $0.24 \mathrm{~km}^{3} / \mathrm{ka}$; Hildreth and Lanphere 1994), and Seguam, Aleutians, USA $\left(0.25 \mathrm{~km}^{3} / \mathrm{ka}\right.$ : Jicha and Singer 2006). Other volcanoes, however, show higher average rates up to $1 \mathrm{~km}^{3} / \mathrm{ka}$ or even higher (for examples and comparisons, see Jicha and Singer 2006; Hora et al. 2007; Singer et al. 2008). Based on our new ${ }^{40} \mathrm{Ar} /{ }^{\beta 9} \mathrm{Ar}$ ages and taking a significant $\sim 50 \mathrm{~km}^{3}$ volume (Holm 1987) of stage 1 into account, the average eruptive rate for the subsequent cone-building stages 2 and 3 ( $100 \mathrm{ka}$ interval) is higher, $\sim 0.3 \mathrm{~km}^{3} / \mathrm{ka}$. Following these stages and the final flank collapse, only sporadic, peripheral, mostly dacitic and rhyolitic eruptions occurred at a much reduced eruptive rate.

\section{Conclusions}

Planèze analysis of San Francisco Mountain using 10-mresolution DEM, combined with ${ }^{40} \mathrm{Ar} /{ }^{39} \mathrm{Ar}$ dating of stage 2 and 3 cones, helps constrain the final stratovolcano evolution.

(1) The original volcanic cone, including the lobes of many lava flows, can be reconstructed by the DEM analysis of the present-day landform. Using planèzes as remnants of the lower flanks and assuming regular, symmetric cones, we propose a two-cone model. The two restored, adjacent (but not coeval) cones, with 


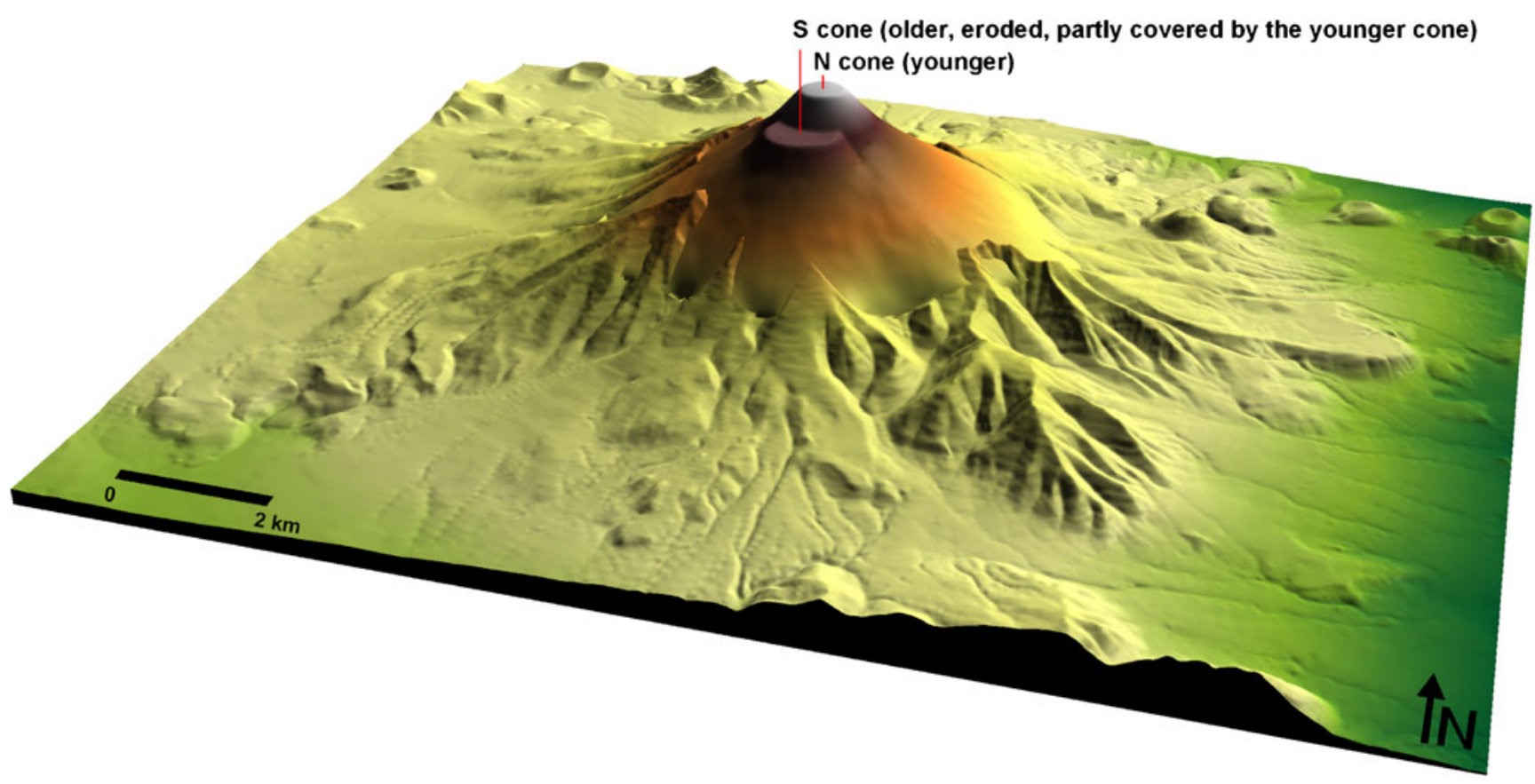

Fig. 9 Simplified DEM-based reconstruction of the paleovolcano of SFM at the end of stage 3. Calculated positions of the adjacent, subsequent cones of Older and Younger Andesites with 700-m-wide summit vent each were used to interpolate the paleosurface over the area of the Inner Basin. The south cone is lowered by $\sim 150 \mathrm{~m}$ as a result of erosion between stage 2 and 3 and prior to sector collapse. The present-day lower slopes of the volcano have not been modified original maximum elevations of 4,350 and 4,460 m, a.s.1., respectively, are the result of the migration of volcanic activity from $\mathrm{S}$ to $\mathrm{N}$.

(2) New ${ }^{40} \mathrm{Ar} /{ }^{39} \mathrm{Ar}$ results are in agreement with the twofold andesite stratigraphy, namely, the succession of the Older and Younger Andesites that may correspond to the $\mathrm{S}$ and $\mathrm{N}$ centers, respectively. The obtained ages fall in two distinct age groups of 589556 and 514-505 ka, supporting two stages possibly separated by a dormant period. The youngest age (505t $9 \mathrm{Ma}$ ) places the final cone-building activity of SFM $\sim 100$ ka earlier than suggested by previous K-Ar determinations. This age is geochronologically indistinguishable from the final cone-building dacitic activity as well as the collapse of the late-stage cone.

(3) At the end of stage 3, the volume of the original volcanic edifice was $\sim 80 \mathrm{~km}^{3}$, of which $\sim 7.5 \mathrm{~km}^{3}$ is the volume removed by the flank failure and subse-
Fig. 10 Topographic cross sections of the Inner Basin. Most parts of the valley bottom are flat. V-shaped sections, indicative of fluvial downcut, are minimal

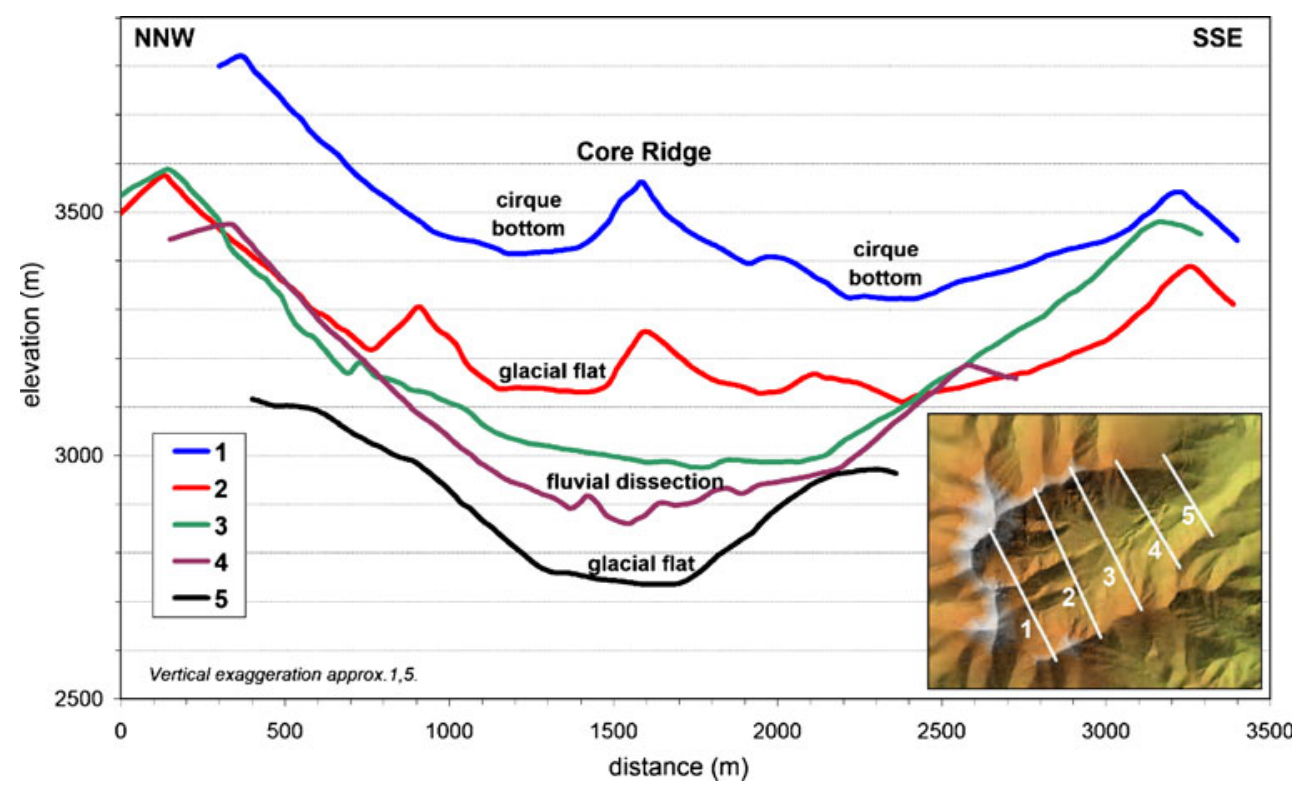


quent erosion within the Inner Basin, and $\sim 2 \mathrm{~km}^{3}$ is the volume eroded from the outer flanks.

(4) On the basis of original volume and radiometric ages, the average eruptive flux of SFM over its lifetime was $\sim 0.2 \mathrm{~km}^{3} / \mathrm{ka}$, whereas the latest cone-building stage may have been characterized by a higher rate of $\sim 0.3 \mathrm{~km}^{3} / \mathrm{ka}$.

Acknowledgments The research work was initiated under a 2004/ 2005 Fulbright Grant to DK at Flagstaff, Northern Arizona University (NAU), AZ, USA, and greatly supported by cooperating scientist Michael Ort. We thank Richard Holm (NAU) for thorough discussions and for providing specimens for ${ }^{40} \mathrm{Ar} /{ }^{39} \mathrm{Ar}$ dating. Financial support for ${ }^{40} \mathrm{Ar} /{ }^{39} \mathrm{Ar}$ dating by the Hungarian Fulbright Committee is gratefully acknowledged. We thank Wendell Duffield (also at NAU) for his comments on stratigraphy, Steve Schilling, Scott Rowland, and Ed Wolfe for helpful reviews, and Michael Clynne for editorial comments and improvements.

Open Access This article is distributed under the terms of the Creative Commons Attribution Noncommercial License which permits any noncommercial use, distribution, and reproduction in any medium, provided the original author(s) and source are credited.

\section{References}

Bezy JV (2003) A guide to the geology of the Flagstaff area. Arizona Geological Survey, Down-to-Earth 14, pp 56

Burrough PA, McDonnell RA (1998) Principles of geographical information systems. Oxford University Press, Oxford

Cotton CA (1952) Volcanoes as landscape forms, 2nd edn. Whitcombe and Tombs, Christchurch

Damon PE, Shafiqullah M, Leventhal JS (1974) K-Ar chronology for the San Francisco volcanic field and rate of erosion of the Little Colorado River. In: Karlstrom TNV, Swann GA, Eastwood RL (eds) Geology of northern Arizona with notes on archeology and paleoclimate. Part 1, Regional studies. Flagstaff, Arizona, Geol Soc Am Rocky Mountain Section Guidebook, pp 221-235

Davidson J, De Silva S (2000) Composite volcanoes. In: Sigurdsson H, Houghton B, McNutt S, Rymer H, Stix J (eds) Encyclopedia of volcanoes. Academic, San Diego, pp 663-681

Dikau R (1989) The application of a digital relief model to landform analysis. In: Raper JF (ed) Three dimensional applications in geographical information systems. Taylor and Francis, London, pp 51-77

Duffield W (1997) Volcanoes of northern Arizona. Grand Canyon Association, Arizona

Ehlers J, Gibbard PL (2004) Quaternary glaciations - extent and chronology. Part II: North America. Geol Mag 144:221-222

Favalli M, Innocenti F, Pareschi MT, Pasquaré G, Mazzarini F, Branca S, Cavarra L, Tibaldi A (1999) The DEM of Mt. Etna: geomorphological and structural implications. Geodin Acta (Paris) 12:279-290

Gibbard PL, Boreham S, Cohen KM, Moscariello (2007) Global chronostratigraphical correlation table for the last 2.7 million years v 2007 b. Subcommission on Quaternary stratigraphy, Dept Geography, Univ Cambridge, UK

Hammond EH (1964) Analysis of properties in landform geography: an application to broadscale landform mapping. Ann Assoc Am Geog 54:11-19

Hildreth W, Lanphere MA (1994) Potassium-argon geochronology of a basalt-andesite-dacite arc system-The Mount Adams Volcanic
Field, Cascade Range of Southern Washington. Geol Soc Am Bull 106:1413-1429

Holm RF (1987) San Francisco Mountain: a Late Cenozoic composite volcano in Northern Arizona. In: Beus SS (ed) Geol Soc Amer Centennial Field Guide Rocky Mountains Sect 2, pp 389-392

Holm RF (1988) Geologic map of San Francisco Mountain, Elden Mountain and Dry Lake Hills, Coconino County, Arizona. US Geol Surv Misc Invest Ser Map I-1663, scale 1:24,000

Holm RF (2004) Landslide preconditions and collapse of the San Francisco Mountain composite volcano, Arizona, into cold debris avalanches in Late Pleistocene. J Geol 112:335-348

Holm RF, Moore RB (1987) Holocene scoria cone and lava flows at Sunset Crater, northern Arizona. In: Beus SS (ed) Geol Soc Amer Centennial Field Guide Rocky Mountains Sect 2, pp 393-397

Hora JM, Singer BS, Wörner G (2007) Volcano evolution and eruptive flux on the thick crust of the Andean Central Volcanic Zone: ${ }^{40} \mathrm{Ar} /{ }^{39} \mathrm{Ar}$ constraints from Volcán Parinacota, Chile. Geol Soc Amer Bull 119:343-362

Jicha BR, Singer BS (2006) Volcanic history and magmatic evolution of Seguam Island, Aleutian Island arc, Alaska. Geol Soc Am Bull 118:805-822

Karátson D (1996) Rates and factors of stratovolcano degradation in a continental climate: a complex morphometric analysis of nineteen Neogene/Quaternary crater remnants in the Carpathians. J Volcanol Geotherm Res 73:65-78

Karátson D, Thouret JCL, Moriya I, Lomoschitz A (1999) Erosion calderas: origins, processes, structural and climatic control. Bull Volcanol 61:174-193

Love DW, Connell SD (2005) Late Neogene drainage development on the southeastern Colorado Plateau, New Mexico. N Mex Mus Nat Hist Sci Bull 28:151-169

Ludwig R, Schneider P (2006) Validation of digital elevation models from SRTM X-SAR for applications in hydrologic modeling. ISPRS J Photogram Rem Sens 60:339-358

McKee EH, Damon PE, Shafiqullah M, Harris RC, Spencer JE (1998) Compilation of unpublished USGS and University of Arizona $\mathrm{K}-\mathrm{Ar}$ dates of volcanic rocks of the San Francisco volcanic field, northern Arizona. Ariz Geol Surv Open File Rep 98-2

Moore RB, Wolfe EW (1987) Geologic map of the east part of the San Francisco volcanic field, north-central Arizona. US Geol Surv Misc Field Studies Map MF 1960, scale 1:50,000

Morgan P, Sass JH, Duffield W (2004) Geothermal resource evaluation program of the Eastern San Francisco Volcanic Field, Arizona. Unpublished final report to the Department of Energy, Project GRED II, Agreement \# DE-FC04-2002AL68298, Department of Geology, Northern Arizona University, pp 40

Newhall CG, Ulrich GE, Wolfe EW (1987) Geologic map of the southwest part of the San Francisco volcanic field, north-central Arizona. US Geol Surv Misc Field Studies Map MF 1958, scale $1: 50,000$

Ollier C (1988) Volcanoes. Basil Blackwell, Oxford

Parsons T, McCarthy J (1995) The active southwest margin of the Colorado Plateau: uplift of mantle origin. Geol Soc Am Bull 107:139-147

Perry FV, Baldridge WS, DePaolo J, Shafiqullah M (1990) Evolution of a magmatic system during continental extension: the Mount Taylor volcanic field, New Mexico. J Geophys Res 95:1932719348

Renne PR, Swisher CC, Deino AL, Karner DB, Owens TL, De Paolo DJ (1998) Intercalibration of standards, absolute ages, and uncertainties in ${ }^{40} \mathrm{Ar} /{ }^{39} \mathrm{Ar}$ dating. Chem Geol 145:117-152

Robinson H (1913) The San Franciscan Volcanic Field, Arizona. US Geol Surv Prof Pap 76:1-213

Singer BS, Thompson RA, Dungan MA, Feeley TC, Nelson ST, Pickens JC, Brown LL, Wulff AW, Davidson JP, Metzger J (1997) Volcanism and erosion during the past $930 \mathrm{ky}$ at the 
Tatara-San Pedro complex, Chilean Andes. Geol Soc Am Bull 109:127-14

Singer BS, Jicha BR, Naranjo JA, Lara LE, Moreno-Roa H, Harper MA (2008) Eruptive history, geochronology, and magmatic evolution of the Puyehue-Cordon Caulle volcanic complex, Chile. Geol Soc Am Bull 120:599-616

Smiley TL (1958) The geology and dating of Sunset Crater, Flagstaff, Arizona. Ninth field conference guidebook. New Mexico Geological Society, Socorro, pp 186-190

Steiger RH, Jäger E (1977) Subcommission on geo-chronology: convention on the use of decay constants in geo- and cosmochronology. Earth Planet Sci Lett 36:359-362

Székely B, Karátson D (2004) DEM-based volcanic geomorphology as a tool for reconstructing volcanic edifices: examples from the Börzsöny Mts, North Hungary. Geomorphology 63:25-37

Tanaka KL, Shoemaker EM, Ulrich GE, Wolfe EW (1986) Migration of volcanism in the San Francisco volcanic field, Arizona. Geol Soc Am Bull 97:129-141

Updike RG (1977) The geology of the San Francisco Peaks, Arizona. $\mathrm{PhD}$ thesis, Arizona State University, Tempe, Arizona

Wolfe EW (1984) The volcanic landscape of the San Francisco Volcanic Field. In: Smiley TL, Nations JD, Péwé TL, Schafer JP (eds) Landscapes of Arizona. University Press of America, Lanham, Md, pp 111-136

Wolfe EW (1990) San Francisco, Arizona. In: Wood CA, Kienle J (eds) Volcanoes of North America. Cambridge Univ Press, Cambridge, pp 278-280

Wolfe EW, Ulrich GE, Holm RF, Moore RB, Newhall CG (1987) Geologic map of the central part of the San Francisco Volcanic Field, North Central Arizona. US Geol Surv Misc Field Studies Map MF-1959, scale 1:50,000

Wood CA (1978) Morphometric evolution of composite volcanoes. Geophys Res Lett 5:437-439

Wood CA, Baldridge S (1990) Volcano tectonics of the Western United States. In: Wood CA, Kienle J (eds) Volcanoes of North America. Cambridge Univ Press, Cambridge, pp 147154

Wright R, Garbeil H, Baloga SM, Mouginis-Mark PJ (2006) An assessment of shuttle radar topography mission digital elevation data for studies of volcano morphology. Rem Sens Env 105:4153

Zhang W, Montgomery DR (1994) Digital elevation model grid size, landscape representation, and hydrologic simulations. Water Resourc Res 30:1019-1028 